\title{
Economic Approach to Combat Violence Against Children in Indonesia
}

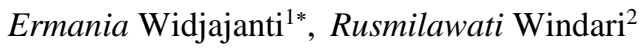 \\ ${ }^{1}$ Faculty of Law Trisakti University, Jakarta, Indonesia \\ ${ }^{2}$ Faculty of Law Trunojoyo Madura University, Madura, Indonesia
}

\begin{abstract}
The current problem of crime countermeasure should be viewed not only as a mere juridical-normative problem, but also cover other areas of life. Aside from being a violation of human rights, the existence of these sanctions are not more than a state shortcut because the conventional sanctions function less optimally. Proportionality of the costs expended compared with the benefits gained is important to measure the efficiency and effectiveness of how crime is overcome . Nowadays, violence against children, a crucial problem for Indonesia, requires countermeasures that are not only effective but also efficient, it is necessary for an economic approach to estimate potential costs of violence against children, therefore it can be a source of information for policy makers or authorities in order to protect children from all forms of violence. It is a reasonable demand if crime countermeasure in the era of globalization does not only empower the strength of the normative aspects of legislation an sich, but it also needs to involve economic considerations in it. The legal issues examined in this article are the urgency of cost analysis as a policy to overcome the crime of violence against children
\end{abstract}

\section{Background}

The majority of children in Indonesia are still vulnerable to being victims of violence. Various types of violence, physical, psychological, and sexual violence (including child trafficking) are particular threats to children. In fact, some of them are done in brutal ways. For instance, a case of violence against Angeline in Bali. This 7-year-old child is alleged to have repeatedly been the victim of physical and psychological violence by her adopted mother and finally was led to her death. There is another violence that happened to Putri Nur Fauziah in Kalideres. This 9-year-old child was found in a deplorable condition, wrapped in cardboard and allegedly experienced several types of violence, namely persecution, rape, and murder.

There is no exact definition related to child abuse. Indra Sugiarno defines it as a brutal act carried out by someone who is supposed to take care and protect children (care taker) physically, sexually and emotionally [1]. Violence is in unlimited space, time and even the quality of the perpetrator. Children can become victims of violence anywhere, from their family, school, and the bigger community. The perpetrator can be anyone. To combat this

${ }^{*}$ Corresponding Author: erwid_farel@yahoo.com 
child abuse, the government as a policy maker, stakes holder, and child protection activist must admit that crime is not only a legal matter, but also a matter of other areas of life, such as economics, social affairs, culture, and psychology.

The field of life that also influences and plays an important role in globalization era is the economy field. Human attitude with the impacts has always economic considerations, as well as in the field of law. According to TJ. Gunawan, the economy field refers to the material resources needed to support the life of a larger social system. Therefore, as long as law enforcement also makes use of and influences the existence of material resources of a country, the economy gets inevitably involved in law.

In the criminal justice system, realized or not, directly or indirectly, the phenomenon of crime in a country always involves economic calculations in it. The economic calculation starts at the same time the crime occurs until the impact happens and law enforcement is implemented. In other words, that crime happens causes certain costs borne by the government, community, individuals (victims), and even possibly by the perpetrators themselves, including their families. Analysis of costs expended as a consequence of the crime, hereinafter refers to as cost.

Considering that violence against children nowadays is a crucial problem for Indonesia, which requires not only effective but also efficient solution, therefore it is necessary to apply an economic approach to estimate the potential costs of violence against children to provide sources of information for policy makers or people in charge to protect children from any forms of violence. The formulations of the problem examined in this paper are as follows: What is the urgency of cost analysis of crime countermeasure?

\section{Explanation}

\section{1 Crimes Inhibits National Development Goals}

Crime countermeasure is essentially an effort to realize the goal of a country national development. As the oldest social problem, as old as human civilization itself, the existence of crime is not only able to disrupt the security stability of a country, but also has an effect on the quality of human life and development.

The goal of Indonesia's national development is to realize a community that is materially and spiritually equal, fair, and prosperous based on Pancasila and the 1945 Constitution of the Republic of Indonesia and to run the economy and to realize the social welfare. The problem of crime is a social problem for every country and its existence can interfere the courses of development, and cost analysis is one of the efforts to measure and analyze the efficiency of crime countermeasure .

\subsection{Crime Countermeasure and Economic Analysis Approach}

From the 20th century to present, economy has controlled most areas of life, the trend of crime countermeasure, mainly in European and American countries, began to shift. Crime countermeasure no longer only aims at achieving law enforcement, but also at the same time realizing social welfare. In the era of economic globalization, Adi Sulistiyono also states that the law must be able to play its role to provide law enforcement, at the same time provide the most efficient improvements in the national economic system [2].

In connection with the legal function in this globalization era, one of the Indonesian criminal law experts, Romli Atmasasmita also believes that globalization era is an era of global welfare, which can only be achieved if a nation or country puts its constitution on and within the context of good/profit and mutual benefit [3]. 
According to Romli Atmasasmita, the era of economic globalization needs a shifting of view of the placement of legal functions and roles in the 21 st century, which is no longer based on community's (individual's) compliance to law, but the law must function to provide distributive justice allocation in structuring the community life, at the same time give power to the national economic system that is fair and proportional in benefits distribution [3].

Related to the context of criminal law, the criminal law is supposed to function and play a role in preventing or overcoming crime, at the same time protecting the interest of national economy and finance. Whereas the imposition of criminal sanctions itself does not only function to create a deterrent effect but it must also be able to encourage and secure the stability and the climate of national economy and finance.

Referring to some ideas above, it is a reasonable demand that crime countermeasure in this globalization does not only empowers the normative aspects of legislation in an sich, but it also needs to involve economic considerations in it, Considering that every crime countermeasure requires fund from national finance(the one comes from public taxes), therefore the use must be accountable for the most benefit of the society.

\subsection{The Urgency of the Economic Approach in Criminal Countermeasures}

The use of an economic approach in assessing crime is considered more than just useful in crime countermeasure. This is supported by the opinion of Andrea Reda that the use of economics excels in [3]:

"Provides a scientific theory to predict the effect of legal sanctions on behavior;provides a useful normative standard for evaluating law and policy;predicts the effects of policies on another important value the distribution of income and wealth".

Based on the above opinion, it is obvious that the use of economic principles in overcoming crime has a series of benefits, not only to predict the impact of bad behavior and the sanction imposition, but it is also believed to be able to evaluate the effectiveness of the implementation of legal rules and policies, and to predict the impact on income and community welfare.

In the context of criminal law, Romli Atmasasmita states that the absence of normative standards to evaluate criminal law and policies that have been implemented has resulted in success evaluation measurement based solely on the number of criminal cases that have been inkracht, without knowing the success of the benefits for the community and the prisoners concerned [3]. Therefore, the use of an economic analysis approach is considered more capable to measure and estimate the success of a crime countermeasure with rational measures.

In addition, it is necessary to consider the opinion of Samanta Brand and Richard Price in an article entitled "Economic and Social Costs of Crime", which says that "crime imposes a huge cost on community". In other words, crime countermeasure efforts are expensive, and it is the people who actually bear enormous costs for the emergence of the crimes.

Samantha Brand and Richard Price, in this case, detail some benefits of the analysis of crime economic costs, as follows [4] :

a. Achieving the greatest impact on crime for the money spent. The use of an economic approach in analyzing crime is able to increase awareness for policy makers and public about the overall impact of crime on community.

b. Having a better informed decisions

The output of economic analysis can also be used as a consideration to determine a more effective and efficient crime countermeasure policy.

c. Policy Appraisal and Policy Evaluation

In addition to being used to assess the proposed policy benefits (as policy appraisal), this analysis can also be used to evaluate the on-going policy success. 


\subsection{The Cost of the Crime of Policy to combat the Violence against Children}

Cost and benefit analysis is actually a program used by public policy analysts a few years ago, which could be traced by economists in the 19th century. The purpose of this analysis was initially to evaluate various development projects, as well as several regulations in the matter of land and environment.

According to N. Gregory Mankiw (2011), Cost is "what you give up to get it" [5], It is everything that is sacrificed or expended to get something. While, the crime by Bentham is defined as "an act which is deemed necessary to be, because of the harm which produces or tends to produce" [6]. Based on the definition, the cost of crime can then be interpreted as everything issued to overcome crime.

In some literature, law experts classify crime costs into various variants, including the following:

Gray divides the cost of crime as follows [6] :

a) Opportunity Cost

It is lost or sacrificed expenses because of certain choices.

b) External Cost atau external diseconomies

It is a cost expended by individual or other party that has no direct relevance to the act

c) Social Cost

It is the cost resulted from each activity that reduces the welfare of the community. Jacek Czabanski in this case argues that the cost of crime happens because the public avoid the bad impacts of crime, and bearing certain costs due to victimization. Czabanski also adds that it is very unlikely to make the community truly safe from crime, but it is possible to make them a little safer [7].

Based on statistical data, the population of Indonesian children in 2012 was estimated at 240 million, and would continue to experience a significant increase in the following years. From this population, the Survey on Violence Against Children (SKTA) conducted by the Ministry of Social Affairs, KPPA, Bappenas, BPS, Unicef and the Centers for desease Control and Prevention, USA in 2013, it was known that children aged 7 to 13 experienced several variants of violence, as follows:

Table 1. Number and Prevalence of Victims of Sexual Violence against children [8].

\begin{tabular}{|l|l|l|}
\hline Types of Violence & \multicolumn{1}{|c|}{ Boy } & \multicolumn{1}{c|}{ Girl } \\
\hline Physical violence & 3 millions & 1,5 millions \\
\hline Prevalence & 1 out of 4 & 1 out of 7 \\
\hline Psychic violence & 1,4 millions & 1,2 millions \\
\hline Prevalence & 1 out of 8 & 1 out of 9 \\
\hline Sexual violence & 900.000 & 600.000 \\
\hline Prevalence & 1 out of 12 & 1 out of 19 \\
\hline
\end{tabular}

From the above matrix, it is entirely known that more than 4 (four) million children both male and female experienced physical violence, while psychic violence was estimated to be more than 2 million children as the victims, and sexual violence happened to more than 1 million children. Particularly, sexual violence, in 2015 increased significantly compared to other types of violence. The Ministry of Women's Empowerment and Child Protection (Kemeneg PP-PA) noted that $60 \%$ of child abuse cases occurring in 2015 were sexual violence against children..

The negative impacts caused by violence against children can be seen in the following table: 
Table 2. Disadvantageous of violence against children [9].

\begin{tabular}{|l|l|}
\hline $\begin{array}{l}\text { Disadvantageous } \\
\text { category }\end{array}$ & \multicolumn{1}{|c|}{ Type } \\
\hline $\begin{array}{l}\text { Physical Health } \\
\text { Disorde }\end{array}$ & $\begin{array}{l}\text { Death, injury, disability, suffering from certain } \\
\text { diseases }\end{array}$ \\
\hline $\begin{array}{l}\text { Sexual \& Reproductive } \\
\text { Disorders }\end{array}$ & $\begin{array}{l}\text { Reproductive health disorders, unwanted } \\
\text { pregnancies, sexual diseases, and other sexual } \\
\text { behavior irregularities. }\end{array}$ \\
\hline Psychological disorders & $\begin{array}{l}\text { Trauma, fear, stress, shame, inhibition of } \\
\text { psychiatric development, personality disorders } \\
\text { with misbehavior, violent or criminal } \\
\text { behavior, loss of confidence, and other } \\
\text { psychic diseases }\end{array}$ \\
\hline Financial Losses & $\begin{array}{l}\text { Direct Cost in the form of care, doctor fees or } \\
\text { other health services }\end{array}$ \\
\hline $\begin{array}{l}\text { Indirect Cost, for example, decreased } \\
\text { productivity, disability, and decreased quality } \\
\text { of life }\end{array}$ \\
\hline $\begin{array}{l}\text { Costs of Law Enforcement and other social } \\
\text { institutions }\end{array}$ \\
\hline
\end{tabular}

The following are some of the government's efforts to combat violence against children, including:

a. Penal Efforts

Penal effort is an effort to overcome crime through criminal law. Regarding this violence against children, there are several laws and regulations that are specifically implemented because they regulate the prohibition of violence against children with the following criminal sanctions,: Law Number 23 of 2002 concerning child protection juncto Act Number 35 of 2014 and Law Number 23 of 2004 concerning Elimination of Domestic Violence. The three laws regulate sanctions that are more serious than the KUHP to be imposed on perpetrators of violence. The average sanction imposed is in the form of imprisonment of more than 3 (three) years and a fine of more than 9 million. In addition, the law of some areas such as Bandung, Riau Islands, Surabaya also has regional regulations specifically related to child protection. However, the nature of the regional regulation certainly cannot be categorized as a penal effort

b. Non Penal Effort

Non-penal effort is an effort to overcome crime by using supports outside the criminal law which is pre-emptive, preventive and curative efforts. Those efforts are taken before the crime happens, and afterwards. In connection with violence against children, the efforts that have been carried out by the government include the following: anti-violence socialization and education in the Family (in accordance with the Regulation of Pemeneg PP-PA Number 02 of 2011), Rehabilitation, Counseling, recovery of physical and psychological health, provision of legal assistance and advocacy, social reintegration and repatriation programs (as formulated in Permeneg PP-PA Number 01 of 2010 concerning Integrated Minimum Service Standards for Victims of Violence). In addition, the government also runs the TESA Program, Child Protection Homes, Proper city for children to Ideal village for child protection, such as Gunem Village in Rembang. 
c. Use the best of Mass Media to socialize the prohibition of violence against children, both online and conventional.

The estimated category of cost which is expended in protecting children from violence is detailed as follows:

Table.3. Category of Cost of Violence Against Children [10].

\begin{tabular}{|c|c|}
\hline Cost Category & $\begin{array}{c}\text { The party in charge of } \\
\text { expenses }\end{array}$ \\
\hline \multicolumn{2}{|l|}{ PUBLIC COST SECTOR: } \\
\hline $\begin{array}{l}\text { Cost of Criminal Justice System (starting } \\
\text { from the cost of investigation, prosecution, } \\
\text { examination in court to attorney's fee and } \\
\text { sanction imposition) }\end{array}$ & Government \\
\hline Cost of legislation Proccess & Government \\
\hline $\begin{array}{l}\text { Cost of Prevention by Governmental } \\
\text { Institutions (consisting of costs expended } \\
\text { by government agencies, such as related } \\
\text { ministries and KPAI), can be in the form } \\
\text { of non-criminal program costs such as } \\
\text { socialization costs, education, advocacy, } \\
\text { legal assistance, rehabilitation, } \\
\text { reintegration, compensation, counseling, } \\
\text { and other victim services. }\end{array}$ & Government \\
\hline $\begin{array}{l}\text { Cost of Prevention by NGO (costs } \\
\text { expended by NGOs in the field of child } \\
\text { protection such as the National Child } \\
\text { Commission, ECPAT, Child Fund, Unicef, } \\
\text { Save Children) }\end{array}$ & NGO \\
\hline \multicolumn{2}{|l|}{ COST OF VICTIMS: } \\
\hline $\begin{array}{l}\text { Direct cost (tangible cost), can be in the } \\
\text { form of doctor's fee, medication, other } \\
\text { health recovery, and victim recovery } \\
\text { services. }\end{array}$ & Victim / government \\
\hline $\begin{array}{l}\text { Indirect Cost (intangible cost)t, can be a } \\
\text { decrease in quality of life, lost schooldays, } \\
\text { injury and suffering, loss of excitement, } \\
\text { fear, trauma, even death. }\end{array}$ & Victim \\
\hline \multicolumn{2}{|l|}{ COST OF OPPORTUNITY: } \\
\hline $\begin{array}{l}\text { Incarcerated Offender, can be in the form } \\
\text { of loss of income, productivity, the value } \\
\text { of freedom, and psychological costs for the } \\
\text { family, the feeling of shame. }\end{array}$ & $\begin{array}{l}\text { Perpetrator and or his/her } \\
\text { family }\end{array}$ \\
\hline $\begin{array}{l}\text { Direct losses of property, can be in the } \\
\text { form of property losses because they have } \\
\text { to pay fine. }\end{array}$ & Perpetrator \\
\hline \multicolumn{2}{|l|}{$\begin{array}{l}\text { COST OF SOCIETY RESPONSE TO } \\
\text { CRIME: }\end{array}$} \\
\hline Private safety Cost & Society \\
\hline Fear of Crime & Society \\
\hline $\begin{array}{l}\text { Community treatment dan neighbourhood } \\
\text { Programs }\end{array}$ & Community \\
\hline
\end{tabular}


\begin{tabular}{|l|l|}
\hline Private therapy or counselling & Potential Victims \\
\hline
\end{tabular}

\section{Conclusion}

Based on the description of the discussion above, the conclusion is that to overcome crime, economic analysis plays an important role as one of the solutions in overcoming the amount of costs expended by the government and individuals as the impact of crime. This economic analysis can be used to measure and evaluate the level of success of a crime countermeasure policy with rational measures. In addition, its existence can be used to predict the effect of the imposition of legal sanctions and the implementation of a rule and policy on the state budget and public welfare, therefore the presence of this economic analysis can later estimate the amount of the cost at the same time rationalize the crime countermeasure budget for the greatest prosperity of the community.

\section{Recommendation}

What can be recommended as a follow-up to this article are as follow:

a. The government should reevaluate the child protection system that has been applied in Indonesia so far. The child protection system involves 3 major ministry institutions, the Ministry of PP-PA, Ministry of Social Affairs, and Ministry of Communication and Information PMK seems to have been less effective and efficient in overcoming violence against children. This is due to the lack of coordination and the involvement of large costs.

b. Referring to the first recommendation, it is better to omit some structures in the child protection system. In this case in accordance with the nomenclature, only one ministry institution is functioned to carry out child protection efforts. Furthermore, at the level of practice, the government should optimize the function of the Indonesian Child Protection Committee (KPAI), as the only government institution by Law No. 23 of 2002 was given a mandate to protect children.

\section{Reference}

1. I. Sugiarno, in the children's profile: Data Kekerasan Anak realeased by KPP-PA, www.Kemenpppa.go.id, accessed on 02 Februari 2011

2. A. Sulistiyono, M. Rustamaji, Hukum Ekonomi Sebagai Panglima (Masmedia Buana Pustaka, Sidoarjo, 2009)

3. R. Atmasasmita, Rekonstruksi Hukum Pidana Melalui Pedekatan Analisis Ekonomi, the article was presented at National Conference entitled "Analisis Ekonomi Terhadap Hukum: Suatu Tinjauan Dalam Pembangunan Hukum” (Fakutas Hukum Universitas Muhammadiyah Jakarta, Jakarta, 14 November 2015)

4. S. Brandt, R. Price, The Economic and Social Costs of Crime (Home Office Research Study, London, 2000)

5. N.G. Mankiw, Principles of Microeconomics (Sixth edition) (South Western Cengage Learning, 2011)

6. C. M. Gray, Costs of Crime (Sage Publications) (Beverly Hills, London, 1979)

7. J. Czabanski, Estimates of Costs of Crime (Springer publication, Polandia, 2008)

8. E. Suharto, abstracted from Presentation entitled "Situasi Anak 2015". Directorate of Children, the Ministry of Social Affairs, October 2015 
9. The table has been re-modified referring to World Report Violence Against Children, the official speech of Secretary-General's Study On Violence Against Children, Pp. 38-39 (United Nations, Geneva, Swiss, 2006)

10. M. A. Cohen, NCJRS 4, Pp. 263-315 (2000) 